\title{
Seasonal and interpopulational morphometry variation of Platyscytus decempunctatus (Carvalho 1945) (Heteroptera: Miridae)
}

\author{
Evaldo Martins Pires ${ }^{1,3}$, Raul Narciso Carvalho Guedes ${ }^{1}$, \\ José Eduardo Serrão ${ }^{2}$ \& Paulo Sérgio Fiuza Ferreira ${ }^{1}$ \\ ${ }^{1}$ Departamento de Biologia Animal/Entomologia, Universidade Federal de Viçosa - UFV, \\ Avenida Peter Henry Rolfs, s/n Campus Universitário, CEP 36570-000, Viçosa, MG, Brazil \\ ${ }^{2}$ Laboratório de Morfologia de Insetos, Departamento de Biologia Geral, \\ Universidade Federal de Viçosa - UFV, \\ Avenida Peter Henry Rolfs, s/n, Campus Universitário, CEP 36570-000, Viçosa, MG, Brazil \\ ${ }^{3}$ Corresponding author: Evaldo Martins Pires, e-mail: evaldo.pires@gmail.com
}

PIRES, E.M., GUEDES, R.N.C., SERRÃO, J.E. \& FERREIRA, P.S.F. 2008. Seasonal and interpopulational morphometry variation of Platyscytus decempunctatus (Carvalho 1945) (Heteroptera: Miridae). Biota Neotrop. 8(2): http://www.biotaneotropica.org.br/v8n2/en/abstract?article+bn00308022008.

Abstract: A morphometry study was carried out with Platyscytus decempunctatus (Carvalho 1945) collected during the dry and wet seasons in Viçosa county, state of Minas Gerais, Brazil and in other 23 counties from the states of Minas Gerais and Rio de Janeiro in Brazil. A total of 30 males and 30 females were collected in Viçosa at each season and additional insects ( 20 males and 20 females) were collected at each county surveyed. The analysis with 27 morphological traits was carried out to verify the seasonal influence, differences between sexes and among populations in specimens from Viçosa. The females of P. decempunctatus collected in Viçosa were larger than the males in most of the traits evaluated in both seasons (dry and wet). The males showed only two body traits larger than the females. Interpopulational morphometry differences of $P$. decempunctatus were significantly correlated with geographic distance among sampling sites.

Keywords: Platyscytus decempunctatus, morphometry, secondary sexual traits, dissimilarity.

PIRES, E.M., GUEDES, R.N.C., SERRÃO, J.E. \& FERREIRA, P.S.F. 2008. Variação morfométrica sazonal e interpopulacional de Platyscytus decempunctatus (Carvalho 1945) (Heteroptera: Miridae). Biota Neotrop. 8(2): http://www.biotaneotropica.org.br/v8n2/pt/abstract?article+bn00308022008.

Resumo: Foi realizado um estudo morfométrico com Platyscytus decempunctatus (Carvalho 1945) coletados durante as estações seca e úmida no município de Viçosa, MG e em 23 municípios distribuídos pelos estados de Minas Gerais e Rio de Janeiro. Foram utilizados 30 machos e 30 fêmeas por estação no estudo de Viçosa e insetos adicionais ( 20 machos e 20 fêmeas) de cada um dos 23 municípios amostrados. Foram analisadas 27 características morfológicas a fim de verificar a influência sazonal e diferenças no dimorfismo sexual em indivíduos de Viçosa e diferenças entre as populações amostradas. As fêmeas de $P$. decempunctatus coletadas em Viçosa foram maiores que os machos na maioria das características avaliadas em ambas as estação (seca e úmida). Os machos apresentaram somente duas características corporais maiores que as fêmeas. Diferenças morfométricas interpopulacionais em P. decempunctatus se correlacionaram à distância geográfica entre os locais de coleta.

Palavras-chave: Platyscytus decempunctatus, morfometria, caracteres sexuais secundários, dissimilaridade. 


\section{Introduction}

Platyscytus decempunctatus is a small phytophagous mirid found only on plants of Solanum cernuun Vell 1829 (Solanaceae), where they develop throughout its life cycle. This species is easily recognized by its dorsal body surface with orange and black spots, pronotal disc and cuneus without spots or marks, scutellum with two lateral reddish or orange spots, wing membrane with two rounded spots, two black marks on the second antennal segment and also 10 dorsal spots on hemelytron (Carvalho 1945).

The knowledge about $P$. decempunctatus is restricted to its initial description and re-description (Carvalho 1945, 1951), occurrence associated with the host plant (Carvalho 1945, 1951, Ferreira et al. 2001) and internal morphology (Pires et al. 2007). Nothing is known about its behavior or biological activities.

Morphometry studies are currently playing a major role in various fields of the entomology, like in the description of new species (Bernardes et al. 2006, Ferreira \& Coelho 2006) and immature stages (Grazia \& Frey-da-Silva 2001, Prezoto \& Gobbi 2005, Silva et al. 2006, Smith 1979), in distinction between some species (Santos et al. 2003), in comparative studies of internal morphological structures (Lemos et al. 2001), in studies with asymmetry and developmental stability (Garnier et al. 2006), in recognizing seasonal influence on species morphology (Ferreira et al. 2006), and in distinguishing sexual-related traits in male and female insects (Carlessi et al. 1999, Ferreira et al. 2006). The objective of this research was to recognize morphometrical differences in P. decempunctatus of both sexes collected during the dry and wet seasons in Viçosa, MG and to verify the similarity among populations.

\section{Material and Methods}

A morphometry study was carried out with Platyscytus decempunctatus specimens collected in the dry and wet seasons in Viçosa county (state of Minas Gerais, Brazil). A total of 30 males and 30 females were collected at each season. These specimens were collected on leaves of S. cernuum plants, located in a reserve from the Forestry Department of the Federal University of Viçosa.

The morphometry study was based on 27 morphological traits selected because of the easy recognition of the structures, since $P$. decempunctatus has reduced body size and some structures are difficult to measure. Millimeters were used as the standard unit for all of the evaluated morphological measurements. The measured traits are shown in Figure 1.

For the morphometry study among populations, adults of $P$. decempunctatus were collected on $S$. cernuum plants, and these were collected based on reports about the geographic distribution of this host plant species (Carvalho 1996). Twenty males and 20 females of $P$. decempunctatus were collected in each one of the 23 sites distributed throughout the states of Minas Gerais and Rio de Janeiro, where the Atlantic Forest prevails among the vegetation.

The specimens were collected in nine sites during dry season (Pinheiral, RJ; Piraí, RJ; Volta Redonda, RJ; Araponga, MG (1); Ervália, MG; Guiricema, MG; Paula Cândido, MG; Viçosa, MG and Teixeiras, MG) and 14 places during wet season (Barra Mansa, RJ; Barra do Piraí, RJ; Levi Gasparian, RJ; Paraíba do Sul, RJ; Vassouras, RJ; Araponga, MG (2); Coronel Pacheco, MG; Florestal, MG; Juiz de Fora, MG; Rio Pomba, MG; Tabuleiro, MG; Tocantins, MG; Ubá, MG and Visconde do Rio Branco, MG).

Individuals of $P$. decempunctatus were collected using a manual vacuum and killed with ethyl acetate within a killing jar. The specimens were pinned, identified and separated according to sex in the laboratory of the Regional Museum of the Federal University of Viçosa (UFVB). The specimens were measured using an ocular mi- crometer (Wild Hurbrugg 10x) in a Leica MZ-8 stereomicroscope. The morphometry analysis of the specimens collected in the 23 sites was similar to the study carried out in Viçosa, but the populations were separated according to the season in which they were collected (dry and wet) to eliminate the influence of season in the geographical variation in morphometric traits among populations.

\section{Statistical analysis}

For the study carried out in Viçosa, the morphometrical data was subjected to a two way ( 2 sexes $\times 2$ seasons) multivariate analysis of variance using the procedure GLM with the MANOVA statement from SAS (SAS Institute 2001). Subsequent two-way univariate analyses of variance (PROC GLM; SAS Institute 2001) were carried out for each individual morphological trait complementing the multivariate analysis to recognize the traits that were indeed different between sex and/or season.

For the population study, the morphometrical data was subjected to a two-way ( 2 sexes $\times 23$ sites) multivariate analysis of variance for each season separately following the same procedure described above (i.e., multivariate analysis of variance followed by univariate analyses of variance).

The morphometrical similarity of the males and females among populations of $P$. decempunctatus was estimated through the cluster analysis of non-weighted means and by estimating the mean Euclidian distance (SAEG 9.0. 2005). The dissimilarity indexes thus calculated were subsequently correlated with geographical distance between each pair of sampling sites (PROC CORR, SAS Institute 2001). The geographical distances $(\mathrm{km})$ between sampling sites were obtained through a global positioning system (Ferraz 1980).

\section{Results}

The multivariate analysis of variance of the 27 morphological traits of $P$. decempunctatus (Figure 1) indicated significant effects of sex and interaction season-sex (Wilk's lambda $=0.21, \mathrm{~F}(27,90)=12.41$, $\mathrm{p}<0.0001$ and Wilk's lambda $=0.55, \mathrm{~F}(27,90)=2.7 ; \mathrm{p}=0.0002$, respectively), with no significant effect of season (Wilk's lambda $=0.77$, $\mathrm{F}(27,90)=0.99, \mathrm{p}=0,49)$. The univariate analysis of variance for each of the morphometrical traits showed significant differences in 20 of the 27 traits considered in the general analysis (Table 1). Fourteen traits showed significant interaction season-sex (Table 1). The females collected in both seasons (dry and wet) were larger than males in 18 to 20 evaluated traits (Table 2).

In the population study, the multivariate analysis of variance showed significant effect of sex (Wilk's lambda $=0.41$, $\mathrm{F}(27,245)=12.6, \mathrm{p}<0.0001$ and Wilk's lambda $=0.19$, $\mathrm{F}(27,286)=43.28, \mathrm{p}<0.0001$, respectively), and sampling site (differences among the populations) (Wilk's lambda $=0.0017$, $\mathrm{F}(216,1901)=11.23, \mathrm{p}<0.0001$ and Wilk's lambda $=0.0001$, $\mathrm{F}(351,3402)=10.34, \mathrm{p}<0.0001$, respectively $)$, and interaction sex-sampling site (Wilk's lambda $=0.13, \mathrm{~F}(216,1901)=2.65$, $\mathrm{p}<0.0001$ and Wilk's lambda $=0.02, \mathrm{~F}(351,3402)=0.0216$, $\mathrm{p}<0.0001$, respectively).

The univariate analysis of variance for each morphometrical trait of the specimens collected in the dry season was significant in the general analysis for all of the traits studied (Table 3). Sampling site also significantly affected all of the traits. Sex showed significant effect in 13 out of 20 traits and the interaction sex-sampling place was significant for 16 out of 20 traits.

The general statistical model for trait differences in insects collected during the wet season showed significant differences $(\mathrm{p}<0.05)$ (Table 4). Sampling site showed significant effect for all of the traits considered, and only a single trait (hemelytrum width) did not show 

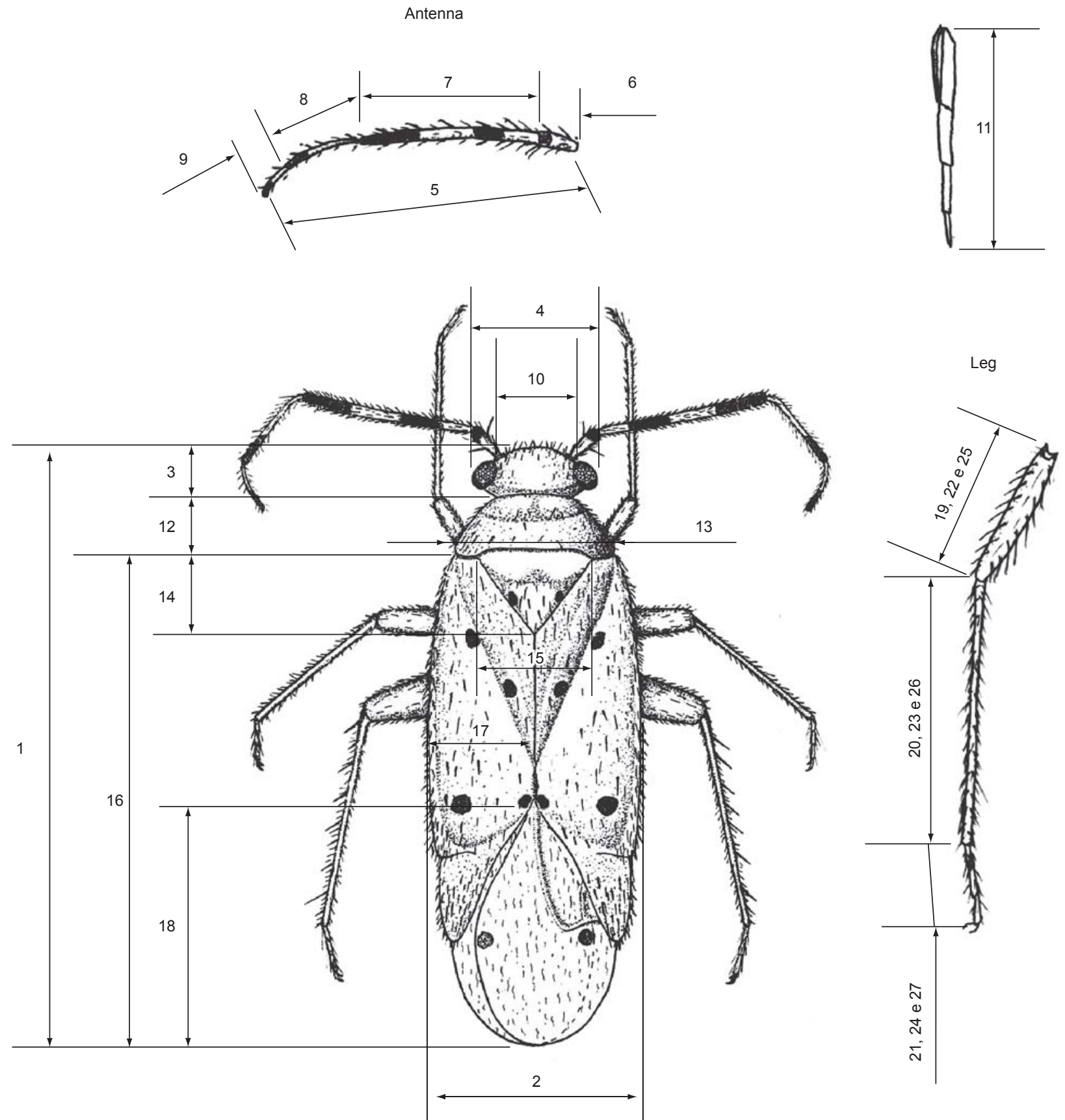

Figure 1. Measurements of morphometry traits of Platyscytus decempunctatus (Heteroptera: Miridae): Body length $(\mathrm{CCO}) 1)=\Sigma$ of the head length, pronotum and hemelytrum; body width (LAC) 2); head length (COC) 3), head width (lateral distance of head including the eyes) (LCA) 4); length of the antenna (CAT) 5); length of $1^{\text {st }}$ antennal segment (CAT1); length of $2^{\text {nd }}$ antennal segment (CAT2); length of $3^{\text {rd }}$ antennal segment (CAT3) and length of $4^{\text {th }}$ antennal segment (CAT4) 6, 7, 8 and 9 respectively); vertex width (distance between eyes) (LVE) 10); rostrum length (CRO); 11); pronotum length (CPR) 12); pronotum width (LPR) 13), scutellum length (CES) 14); apex scutellum width (LES) 15); hemelytrum length (CHE) 16), hemelytrum width (CHE) 17); membrane length (CMB) 18); Length of the anterior femur (CFA) 19), Length of the anterior tibia (CIA) 20); Length of the anterior tarsi (CTA) 21); length of the median femur (CFM) 22); length of the median tibia (CIM) 23), length of the median tarsi (CTM) 24), length of the posterior femur (CFP) 25); length of the posterior tibia (CIP) 26); length of the posterior tarsi (CTP) and 27).

Figura 1. Medidas das características morfométricas de Platyscytus decempunctatus (Heteroptera: Miridae): Comprimento do corpo (CCO) 1$)=\Sigma$ do comprimento da cabeça, pronoto e hemiélitro; largura do corpo (LAC) 2) comprimento da cabeça (COC) 3), largura da cabeça (distância lateral da cabeça incluindo os olhos) (LCA) 4); comprimento da antena (CAT) 5); comprimento do primeiro segmento antenal (CAT1); comprimento do segundo segmento antenal (CAT2); comprimento do terceiro segmento antenal (CAT3) e comprimento do quarto segmento antenal (CAT4) 6, 7, 8 e 9 respectivamente); largura do vértice (distância entre os olhos) (LVE)10); comprimento do rostro (CRO); 11); comprimento do pronoto (CPR) 12); largura do pronoto (LPR) 13), comprimento do escutelo (CES) 14); largura do ápice do escutelo (LES) 15); comprimento do hemiélitro (CHE) 16), largura do hemiélitro (CHE) 17); comprimento da membrana (CMB) 18); Comprimento do fêmur anterior (CFA) 19), Comprimento da tíbia anterior (CIA) 20); Comprimento do tarso anterior (CTA) 21); comprimento do fêmur mediano (CFM) 22); comprimento da tíbia mediana (CIM) 23), comprimento do tarso mediano (CTM) 24), comprimento do fêmur posterior (CFP) 25); comprimento da tíbia posterior (CIP) 26); comprimento do tarso posterior (CTP) e 27). 
Table 1. Univariate analyses of variance (ANOVA) for season and sex differences in 27 different morphological traits of $P$. decempunctatus collected in Viçosa, MG, Brazil.

Tabela 1. Análise de variância univariada (ANOVA) por estação e sexo em 27 diferentes características morfológicas de $P$. decempunctatus coletados em Viçosa, MG, Brasil.

\begin{tabular}{|c|c|c|c|c|c|c|c|c|}
\hline \multirow[t]{3}{*}{ Morphological traits } & \multicolumn{2}{|c|}{ Model } & \multicolumn{6}{|c|}{ Sources of variation } \\
\hline & \multirow[t]{2}{*}{$\mathbf{F}$} & \multirow[t]{2}{*}{$\mathbf{p}$} & \multicolumn{2}{|c|}{ Seasons } & \multicolumn{2}{|c|}{ Sex } & \multicolumn{2}{|c|}{ Season $x$ Sex } \\
\hline & & & $\mathbf{F}$ & $\mathbf{p}$ & $\mathbf{F}$ & $\mathbf{p}$ & $\mathbf{F}$ & $\mathbf{p}$ \\
\hline Body length & 17.26 & $<0.0001^{*}$ & 0.05 & 0.81 & 41.65 & $<0.0001^{*}$ & 10.07 & $0.0019 *$ \\
\hline Body width & 8.24 & $<0.0001^{*}$ & 0.07 & 0.79 & 18.42 & $<0.0001^{*}$ & 6.24 & $0.0139 *$ \\
\hline Head length & 11.99 & $<0.0001^{*}$ & 0.44 & 0.50 & 12.22 & $0.0007 *$ & 23.31 & $<0.0001 *$ \\
\hline Head width & 7.19 & $0.0002 *$ & 0.05 & 0.82 & 10.76 & $0.0014 *$ & 10.76 & $0.0014 *$ \\
\hline Antennal length & 6.64 & $0.0012 *$ & 0.40 & 0.52 & 8.98 & $0.0033^{*}$ & 7.54 & $0.0070 *$ \\
\hline I antennal segment length & 8.92 & $<0.0001^{*}$ & 0.05 & 0.83 & 15.45 & $0.0001 *$ & 11.28 & $0.0011 *$ \\
\hline II antennal segment length & 14.41 & $<0.0001^{*}$ & 1.62 & 0.20 & 30.02 & $<0.0001 *$ & 11.58 & $0.0009 *$ \\
\hline III antennal segment length & 0.36 & 0.7840 & - & - & - & - & - & - \\
\hline IV antennal segment length & 0.20 & 0.8963 & - & - & - & - & - & - \\
\hline Vertex width & 25.71 & $<0.0001^{*}$ & 0.14 & 0.70 & 58.38 & $<0.0001^{*}$ & 18.60 & $<0.0001 *$ \\
\hline Rostrum length & 13.48 & $<0.0001 *$ & 0.19 & 0.66 & 42.72 & $0.0318 *$ & 35.54 & $<0.0001 *$ \\
\hline Pronotum length & 5.17 & $0.0022 *$ & 1.26 & 0.26 & 14.93 & $0.0002 *$ & 11.30 & $0.0010 *$ \\
\hline Pronotum width & 1.31 & 0.2730 & - & - & - & - & - & - \\
\hline Scutellum length & 5.44 & $0.0016^{*}$ & 0.58 & 0.44 & 2.97 & 0.0877 & 0.82 & 0.3685 \\
\hline Scutellum width & 2.67 & 0.0519 & - & - & - & - & - & - \\
\hline Hemelytrum length & 20.64 & $<0.0001^{*}$ & 0.16 & 0.68 & 58.62 & $<0.0001^{*}$ & 3.15 & 0.0784 \\
\hline Hemelytrum width & 5.41 & $0.0016^{*}$ & 8.85 & 0.08 & 6.48 & $0.0122 *$ & 0.89 & 0.3472 \\
\hline Membranous wing length & 21.58 & $<0.0001^{*}$ & 0.14 & 0.70 & 61.84 & $<0.0001^{*}$ & 3.76 & $0.0500 *$ \\
\hline Anterior femur length & 3.27 & 0.0737 & - & - & - & - & - & - \\
\hline Anterior tibia length & 16.92 & $<0.0001^{*}$ & 1.68 & 0.19 & 43.10 & $<0.0001^{*}$ & 5.97 & $0.0161 *$ \\
\hline Anterior tarsi length & 0.75 & 0.5216 & - & - & - & - & - & - \\
\hline Median femur length & 8.66 & $<0.0001^{*}$ & 0.39 & 0.53 & 14.28 & $0.0003 *$ & 11.31 & $0.0010 *$ \\
\hline Median tibia length & 12.84 & $<0.0001^{*}$ & 0.63 & 0.42 & 36.39 & $<0.0001^{*}$ & 1.51 & 0.2219 \\
\hline Median tarsi length & 0.11 & 0.9545 & - & - & - & - & - & - \\
\hline Posterior femur length & 11.51 & $<0.0001^{*}$ & 0.84 & 0.36 & 26.31 & $<0.0001^{*}$ & 7.38 & $0.0076^{*}$ \\
\hline Posterior tibian length & 5.99 & $0.0008 *$ & 0.71 & 0.40 & 15.13 & $0.0002 *$ & 2.11 & 0.1488 \\
\hline Posterior tarsi length & 6.04 & $0.0007 *$ & 1.07 & 0.30 & 15.99 & $0.0001 *$ & 1.07 & 0.3030 \\
\hline
\end{tabular}

*Significantly at $\mathrm{p}<0.05$.

*Significativo para $\mathrm{p}<0,05$

significant effect of sex. The interaction sex-sampling site was significant for 15 out of the 20 traits considered.

The dissimilarity dendograms showed two distinct clusters for both males and females of P. decempunctatus (Figures 2 and 3). The male dendogram showed two large population clusters, one formed by populatins from 13 counties from the state of Minas Gerais and only one county from the state of Rio de Janeiro. In the other cluster, nine counties are from Rio de Janeiro and two are from Minas Gerais (Figure 2). The female dendogram also have two large clusters, one is formed by populations from 12 counties from the state of Minas Gerais and again only one county from Rio de Janeiro. The other group is formed by populations from seven counties from Rio de Janeiro and four from Minas Gerais (Figure 3).

There was significant and positive correlation between the dissimilarity indexes and geographical distances between insects collected at different sampling sites (Table 5). The correlation coef- ficients were 0.79 and 0.67 for males and females collected during the dry season and 0.73 and 0.86 for males and females collected during the wet season respectively. This finding provides support for the hypothesis that populations from closer-located sites resemble each other more closely (Teles et al. 2001).

\section{Discussion}

The females were larger than the males in most of the traits evaluated in both seasons what is common in among several species, because the size body is associated with reproductive features (Renthal et al. 2003). Such finding was also previously reported for morphological studies with others species like Triatoma dimidiata (Heteroptera: Reduviidae) (Lehmann et al. 2005), Podisus mucronatus (Heteroptera: Pentatomidae) (Costello et al. 2002), Oxelytrum discicolle (Coleoptera: Silphidae) (Ferreira et al. 2006), Oncideres dejeani (Coleoptera: Cerambycidae) (Seffrin et al. 2006). 
Table 2. Morphometry differences (mm) ( $\pm \mathrm{SE}$ ) between females and males of P. decempunctatus collected in dry and wet seasons in Viçosa, MG, Brazil. Tabela 2. Diferenças morfométricas (mm) ( \pm Erro Padrão) entre fêmeas e machos de $P$. decempunctatus coletados nas estações seca e úmida em Viçosa, MG, Brasil.

\begin{tabular}{|c|c|c|c|c|}
\hline \multirow[t]{2}{*}{ Morphological traits } & \multicolumn{2}{|c|}{ Dry season } & \multicolumn{2}{|c|}{ Wet season } \\
\hline & Female & Male & Female & Male \\
\hline Body length & $2.93 \pm 0.00 \mathrm{a}$ & $2.81 \pm 0.02 \mathrm{~b}$ & $2.87 \pm 0.02 \mathrm{a}$ & $2.74 \pm 0.01 b$ \\
\hline Head length & $0.23 \pm 0.00 \mathrm{a}$ & $0.22 \pm 0.00 \mathrm{~b}$ & $0.22 \pm 0.00 \mathrm{a}$ & $0.22 \pm 0.00 \mathrm{~b}$ \\
\hline Head width & $0.54 \pm 0.00 \mathrm{a}$ & $0.52 \pm 0.00 \mathrm{~b}$ & $0.52 \pm 0.00 \mathrm{a}$ & $0.50 \pm 0.00 \mathrm{~b}$ \\
\hline I antennal segment length & $0.23 \pm 0.00 \mathrm{a}$ & $0.22 \pm 0.00 \mathrm{~b}$ & $0.22 \pm 0.00 \mathrm{a}$ & $0.22 \pm 0.00 \mathrm{~b}$ \\
\hline II antennal segment length & $0.74 \pm 0.00 \mathrm{~b}$ & $0.83 \pm 0.01 \mathrm{a}$ & $0.72 \pm 0.00 b$ & $0.77 \pm 0.01 \mathrm{a}$ \\
\hline Vertex width & $0.34 \pm 0.00 \mathrm{a}$ & $0.30 \pm 0.00 \mathrm{~b}$ & $0.31 \pm 0.00 \mathrm{a}$ & $0.27 \pm 0.00 \mathrm{~b}$ \\
\hline Rostrum length & $1.16 \pm 0.01 \mathrm{a}$ & $1.03 \pm 0.01 \mathrm{~b}$ & $1.13 \pm 0.01 \mathrm{a}$ & $1.07 \pm 0.02 \mathrm{~b}$ \\
\hline Pronotum length & $0.32 \pm 0.00 \mathrm{a}$ & $0.32 \pm 0.00 \mathrm{~b}$ & $0.31 \pm 0.00 \mathrm{a}$ & $0.29 \pm 0.00 \mathrm{~b}$ \\
\hline Scutellum length & $0.43 \pm 0.00 \mathrm{a}$ & $0.42 \pm 0.00 \mathrm{~b}$ & $0.44 \pm 0.00 \mathrm{a}$ & $0.42 \pm 0.00 \mathrm{~b}$ \\
\hline Hemelytrum length & $2.31 \pm 0.01 \mathrm{a}$ & $2.12 \pm 0.02 b$ & $2.26 \pm 0.02 \mathrm{a}$ & $2.09 \pm 0.02 b$ \\
\hline Hemelytrum width & $0.52 \pm 0.00 \mathrm{a}$ & $0.51 \pm 0.02 \mathrm{~b}$ & $0.60 \pm 0.03 \mathrm{a}$ & $0.49 \pm 0.00 \mathrm{~b}$ \\
\hline Membranous wing length & $1.04 \pm 0.01 \mathrm{a}$ & $0.91 \pm 0.02 b$ & $1.01 \pm 0.01 \mathrm{a}$ & $0.88 \pm 0.01 \mathrm{~b}$ \\
\hline Anterior tibia length & $0.69 \pm 0.00 \mathrm{a}$ & $0.62 \pm 0.01 \mathrm{~b}$ & $0.66 \pm 0.00 \mathrm{a}$ & $0.61 \pm 0.00 \mathrm{~b}$ \\
\hline Median femur length & $0.71 \pm 0.00 \mathrm{a}$ & $0.65 \pm 0.01 \mathrm{~b}$ & $0.66 \pm 0.01 \mathrm{a}$ & $0.62 \pm 0.01 b$ \\
\hline Median tibia length & $0.81 \pm 0.01 \mathrm{a}$ & $0.70 \pm 0.01 \mathrm{~b}$ & $0.78 \pm 0.01 \mathrm{a}$ & $0.70 \pm 0.00 \mathrm{~b}$ \\
\hline Posterior femur length & $0.86 \pm 0.00 \mathrm{a}$ & $0.81 \pm 0.01 \mathrm{~b}$ & $0.84 \pm 0.01 \mathrm{a}$ & $0.76 \pm 0.01 b$ \\
\hline Posterior tibia length & $1.30 \pm 0.01 \mathrm{a}$ & $1.26 \pm 0.01 \mathrm{~b}$ & $1.29 \pm 0.01 \mathrm{a}$ & $1.23 \pm 0.01 \mathrm{~b}$ \\
\hline Posterior tarsi length & $0.37 \pm 0.00 \mathrm{a}$ & $0.34 \pm 0.00 \mathrm{~b}$ & $0.36 \pm 0.00 \mathrm{a}$ & $0.34 \pm 0.00 \mathrm{~b}$ \\
\hline
\end{tabular}

Mean in the seasons, followed by the same letter in a row are not significantly different at $\mathrm{p}<0.05$ by the $\mathrm{F}$ test.

Médias nas estações, seguidas pela mesma letra na linha não são significativamente diferentes para $\mathrm{p}<0,05$ pelo teste $\mathrm{F}$.

Euclidean distance
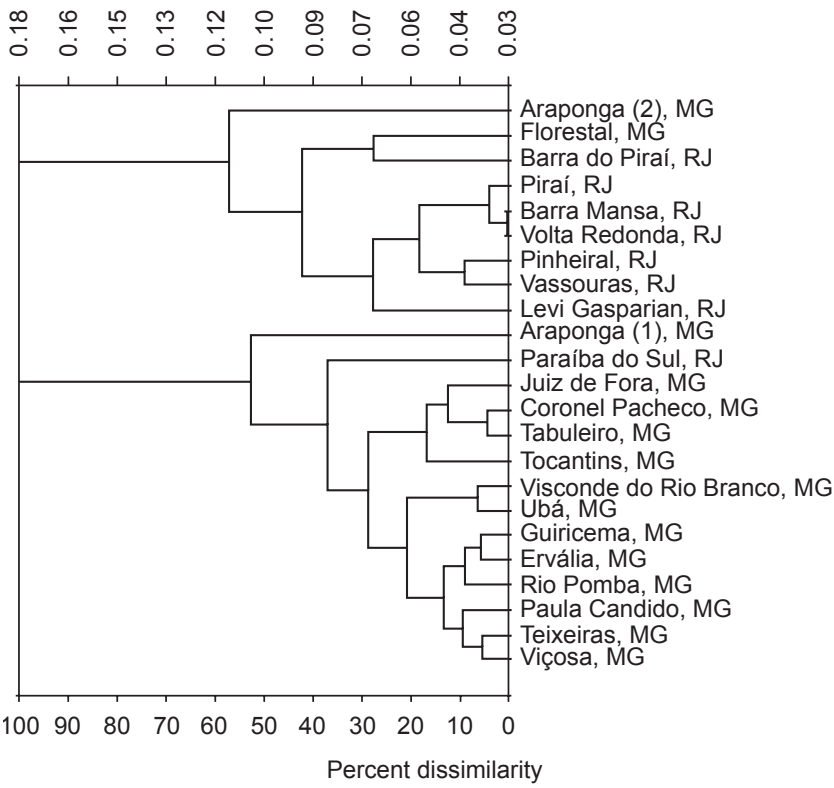

Figure 2. Dissimilarity dendogram among the populations of males of Platyscytus decempunctatus (Heteroptera: Miridae).

Figura 2. Dendograma de dissimilaridade entre as populações de machos de Platyscytus decempunctatus (Heteroptera: Miridae).
Males of $P$. decempunctatus showed only two body traits larger than the females: antennal length and $2^{\text {nd }}$ antennal segment length. Males usually have larger antennae than females because they have more sensory sensilla related to their increased capacity of locating females for mating (Chapman 1998). The meaning of the other body differences observed (Table 3 ) is not clear, but they represent expressions of sexual dimorphism in $P$. decempunctatus.

The dissimilarity dendograms identified combinations between populations due the morphometrical traits. These combinations showed that populations near geographically are more similar, what can be confirmed through of correlation analyses between population dissimilarity and geographical distance between their sampling sites indicated that coefficients showed that populations from closer-located sites resemble each other more closely. Similar results were also reported in the mirid species Polymerus testaceipes, where populations more distant-located showed increased differences in morphometrical traits (Ferreira \& Vilela 1980). This fact can be explained because morphometry variations occur based on phenotypic and/or genotypic quality (Möller \& Swaddle 1997), low level of gene flow due the geographic barriers (Frey et al. 1990), and variations of the habitats where the insects were sampled (Smith \& Patton 1988). However, to know the main cause of the morphological differences among populations of $P$. decempunctatus new studies need to be carried out involving limits of genetic variation, of the habitats sampled and other variables that may occur along the geographic distribution of this species with potential to affect the morphology of $P$. decempunctatus. 
Table 3. Univariate analyses of variance (ANOVA) for differences in sampling sites and sex of the populations of P. decempunctatus collected during the dry season in the states of Minas Gerais and Rio de Janeiro.

Tabela 3. Análise de variância univariada (ANOVA) para diferenças nos pontos de coleta e sexo das populações de $P$. decempunctatus coletados durante a estação seca nos estados de Minas Gerais e Rio de Janeiro.

\begin{tabular}{|c|c|c|c|c|c|c|c|c|}
\hline \multirow[t]{3}{*}{ Morphological traits } & \multicolumn{2}{|c|}{ Model } & \multicolumn{6}{|c|}{ Sources of variation } \\
\hline & \multirow[t]{2}{*}{$\mathbf{F}$} & \multirow[t]{2}{*}{$\mathbf{p}$} & \multicolumn{2}{|c|}{ Place } & \multicolumn{2}{|c|}{ Sex } & \multicolumn{2}{|c|}{ Sex $x$ Place } \\
\hline & & & $\mathbf{F}$ & $\mathbf{p}$ & $\mathbf{F}$ & $\mathbf{p}$ & $\mathbf{F}$ & $\mathbf{p}$ \\
\hline Body length & 54.05 & $<0.0001^{*}$ & 110.48 & $<0.0001^{*}$ & 4.18 & $0.0418 *$ & 3.85 & $0.0003 *$ \\
\hline Body width & 24.47 & $<0.0001^{*}$ & 48.23 & $<0.0001^{*}$ & 0.44 & 0.5088 & 3.72 & $0.0004 *$ \\
\hline Head length & 11.51 & $<0.0001^{*}$ & 20.39 & $<0.0001^{*}$ & 7.94 & $0.0052 *$ & 3.09 & $0.0024 *$ \\
\hline Head width & 28.83 & $<0.0001 *$ & 57.49 & $<0.0001 *$ & 5.68 & $0.0179 *$ & 3.06 & $0.0026^{*}$ \\
\hline Antennal length & 16.48 & $<0.0001^{*}$ & 28.53 & $<0.0001^{*}$ & 45.39 & $<0.0001 *$ & 0.80 & 0.6010 \\
\hline I antennal segment length & 1.63 & $0.0500 *$ & 2.40 & $0.0164 *$ & 0.47 & 0.4914 & 1.02 & 0.4239 \\
\hline II antennal segment length & 38.65 & $<0.0001^{*}$ & 56.20 & $<0.0001^{*}$ & 187.19 & $<0.0001 *$ & 2.52 & $0.0117^{*}$ \\
\hline Vertex width & 22.16 & $<0.0001 *$ & 35.62 & $<0.0001 *$ & 42.15 & $<0.0001 *$ & 6.26 & $<0.0001^{*}$ \\
\hline Rostrum length & 21.41 & $<0.0001^{*}$ & 44.34 & $<0.0001^{*}$ & 0.98 & 0.3236 & 1.03 & 0.4158 \\
\hline Pronotum length & 16.30 & $<0.0001^{*}$ & 30.22 & $<0.0001^{*}$ & 7.42 & $0.0069 *$ & 3.49 & $0.0007 *$ \\
\hline Scutellum length & 4.68 & $<0.0001^{*}$ & 7.89 & $<0.0001^{*}$ & 0.01 & 0.9099 & 2.05 & $0.0411 *$ \\
\hline Hemelytrum length & 47.05 & $<0.0001^{*}$ & 95.98 & $<0.0001^{*}$ & 3.67 & $0.0500 *$ & 3.55 & $0.0006^{*}$ \\
\hline Hemelytrum width & 21.95 & $<0.0001^{*}$ & 41.72 & $<0.0001^{*}$ & 0.72 & 0.3871 & 4.83 & $<0.0001 *$ \\
\hline Membranous wing length & 39.96 & $<0.0001^{*}$ & 83.17 & $<0.0001^{*}$ & 2.26 & 0.1342 & 1.46 & 0.1730 \\
\hline Anterior tibia length & 29.65 & $<0.0001 *$ & 54.64 & $<0.0001 *$ & 15.36 & $0.0001 *$ & 6.45 & $<0.0001 *$ \\
\hline Median femur length & 25.66 & $<0.0001^{*}$ & 48.29 & $<0.0001^{*}$ & 13.20 & $0.0003 *$ & 4.58 & $<0.0001 *$ \\
\hline Median tibia length & 35.23 & $<0.0001^{*}$ & 69.52 & $<0.0001^{*}$ & 11.29 & $0.0009 *$ & 3.94 & $0.0002 *$ \\
\hline Posterior femur length & 36.24 & $<0.0001^{*}$ & 72.37 & $<0.0001^{*}$ & 12.36 & $0.0005 *$ & 3.09 & $0.0024 *$ \\
\hline Posterior tibia length & 85.28 & $<0.0001 *$ & 172.31 & $<0.0001 *$ & 12.97 & $0.0004 *$ & 7.28 & $<0.0001^{*}$ \\
\hline Posterior tarsi length & 6.89 & $<0.0001 *$ & 12.15 & $<0.0001 *$ & 0.01 & 0.9182 & 2.49 & $0.0125 *$ \\
\hline
\end{tabular}

Euclidean distance

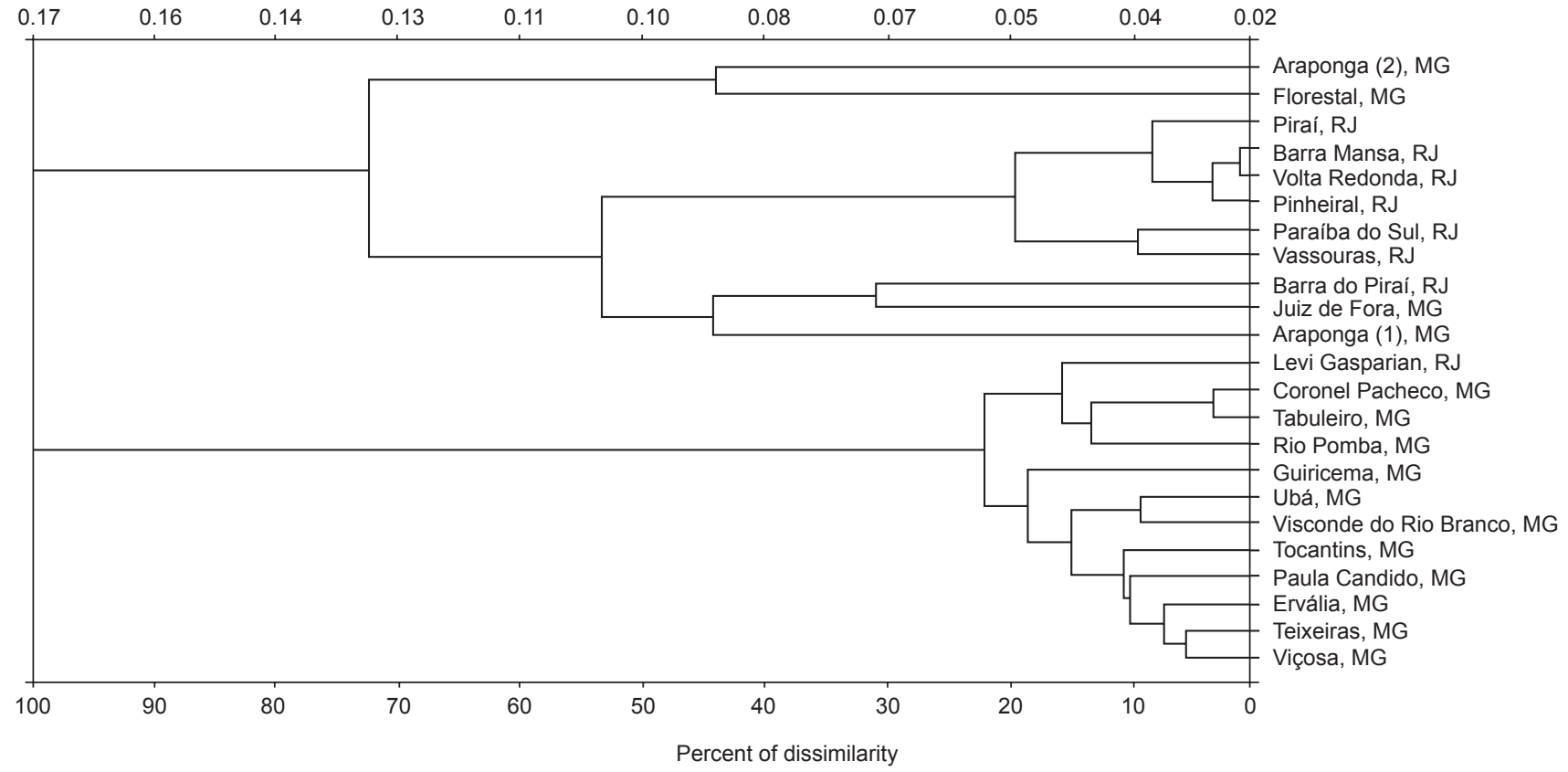

Figure 3. Dissimilarity dendogram among the populations of females of Platyscytus decempunctatus (Heteroptera: Miridae).

Figura 3. Dendograma de dissimilaridade entre as populações de fêmeas de Platyscytus decempunctatus (Heteroptera: Miridae). 
Table 4. Univariate analyses of variance (ANOVA) for differences in sampling sites and sex of the populations of P. decempunctatus collected during the wet season in the states of Minas Gerais and Rio de Janeiro.

Tabela 4. Análise de variância univariada (ANOVA) para diferenças nos pontos de coleta e sexo das populações de P. decempunctatus coletados durante a estação úmida nos estados de Minas Gerais e Rio de Janeiro.

\begin{tabular}{|c|c|c|c|c|c|c|c|c|}
\hline \multirow[t]{3}{*}{ Morphological traits } & \multicolumn{2}{|c|}{ Model } & \multicolumn{6}{|c|}{ Source of variation } \\
\hline & \multirow[t]{2}{*}{$\mathbf{F}$} & \multirow[t]{2}{*}{ p } & \multicolumn{2}{|c|}{ Place } & \multicolumn{2}{|c|}{ Sex } & \multicolumn{2}{|c|}{ Sex $x$ Place } \\
\hline & & & $\mathbf{F}$ & p & $\mathbf{F}$ & $\mathbf{p}$ & $\mathbf{F}$ & p \\
\hline Body length & 47.92 & $<0.0001^{*}$ & 97.43 & $<0.0001^{*}$ & 17.44 & $<0.0001^{*}$ & 0.77 & 0.6945 \\
\hline Body width & 16.01 & $<0.0001^{*}$ & 29.85 & $<0.0001^{*}$ & 6.23 & $0.0131 *$ & 2.91 & $0.0005^{*}$ \\
\hline Head length & 15.07 & $<0.0001^{*}$ & 19.65 & $<0.0001^{*}$ & 38.03 & $<0.0001^{*}$ & 8.73 & $<0.0001 *$ \\
\hline Head width & 25.21 & $<0.0001^{*}$ & 44.91 & $<0.0001^{*}$ & 8.85 & $0.0032 *$ & 6.76 & $<0.0001 *$ \\
\hline Antennal length & 22.90 & $<0.0001^{*}$ & 32.68 & $<0.0001^{*}$ & 171.65 & $<0.0001 *$ & 1.67 & 0.0653 \\
\hline I antennal segment length & 30.30 & $<0.0001^{*}$ & 37.34 & $<0.0001^{*}$ & 157.81 & $<0.0001 *$ & 13.45 & $<0.0001 *$ \\
\hline II antennal segment length & 19.81 & $<0.0001^{*}$ & 26.67 & $<0.0001^{*}$ & 160.26 & $<0.0001 *$ & 2.13 & $0.0124 *$ \\
\hline Vertex width & 18.43 & $<0.0001 *$ & 29.76 & $<0.0001 *$ & 20.20 & $<0.0001 *$ & 6.41 & $<0.0001 *$ \\
\hline Rostrum length & 9.07 & $<0.0001 *$ & 13.07 & $<0.0001^{*}$ & 41.74 & $<0.0001^{*}$ & 2.55 & $0.0024 *$ \\
\hline Pronotum length & 9.65 & $<0.0001 *$ & 16.30 & $<0.0001 *$ & 19.82 & $<0.0001 *$ & 2.22 & $0.0088 *$ \\
\hline Scutellum length & 14.09 & $<0.0001^{*}$ & 24.18 & $<0.0001^{*}$ & 8.44 & $0.0039 *$ & 4.44 & $<0.0001^{*}$ \\
\hline Hemelytrum length & 47.89 & $<0.0001^{*}$ & 96.54 & $<0.0001^{*}$ & 27.53 & $<0.0001 *$ & 0.82 & 0.6430 \\
\hline Hemelytrum width & 13.95 & $<0.0001^{*}$ & 24.04 & $<0.0001^{*}$ & 0.66 & 0.4184 & 2.88 & $0.0006^{*}$ \\
\hline Membranous wing length & 34.34 & $<0.0001^{*}$ & 68.72 & $<0.0001^{*}$ & 18.43 & $<0.0001 *$ & 1.18 & 0.2892 \\
\hline Anterior tibia length & 37.39 & $<0.0001 *$ & 67.92 & $<0.0001^{*}$ & 41.95 & $<0.0001 *$ & 6.52 & $<0.0001 *$ \\
\hline Median femur length & 17.45 & $<0.0001^{*}$ & 31.37 & $<0.0001^{*}$ & 25.98 & $<0.0001^{*}$ & 2.88 & $0.0006 *$ \\
\hline Median tibia length & 51.79 & $<0.0001^{*}$ & 104.64 & $<0.0001^{*}$ & 23.24 & $<0.0001^{*}$ & 1.15 & 0.3191 \\
\hline Posterior femur length & 26.64 & $<0.0001^{*}$ & 46.63 & $<0.0001^{*}$ & 79.26 & $<0.0001^{*}$ & 2.61 & $0.0019 *$ \\
\hline Posterior tibia length & 63.09 & $<0.0001^{*}$ & 125.95 & $<0.0001^{*}$ & 23.04 & $<0.0001^{*}$ & 3.31 & $<0.0001^{*}$ \\
\hline Posterior tarsi length & 7.56 & $<0.0001^{*}$ & 11.53 & $<0.0001^{*}$ & 6.34 & $0.0123 *$ & 3.69 & $<0.0001 *$ \\
\hline
\end{tabular}

Table 5. Correlations between morphometric dissimilarity and geographic distance of populations of $P$. decempunctatus.

Tabela 5. Correlação entre dissimilaridade morfométrica e distância geográfica das populações de $P$. decempunctatus.

\begin{tabular}{clcc}
\hline Seasons & Sex & r & p \\
\hline \multirow{2}{*}{ Dry } & Male & $0.79^{*}$ & $<0.0001$ \\
& Female & $0.67^{*}$ & $<0.0001$ \\
\multirow{2}{*}{ Wet } & Male & $0.73^{*}$ & $<0.0001$ \\
& Female & $0.86^{*}$ & $<0.0001$ \\
\hline
\end{tabular}

\section{Acknowledgements}

We are grateful to CAPES (Foundation from the Brazilian Ministry of Education) and to CNPq (National Counsel of Technological and Scientific Development) for the financial support provided and to Justin Porter (University of Georgia, USA) for reviewing the manuscript.

\section{References}

BERNARDES, J.L.C., GRAZIA, J. \& BARCELLOS, A. 2006. New species of Neotibilis Grazia \& Barcellos (Hemiptera: Pentatomidae: Pentatomini). Neotrop. Entomol. 35(3):344-348.
CARLESSI, L.R.G., CORSEUIL, E. \& SALVADORI, J.R. 1999. Aspectos biológicos e morfométricos de Collaria scenica (Stal) (Hemiptera: Miridae) em trigo. An. Soc. Entomol. Brasil. 28(1):65-73.

CARVALHO, L.F. 1996. Espécies de Solanum das séries cernuum Carv. \& Sheph. e Lepidotum (Dun.) Seithe Holf. (Solanaceae). Pesq. (Ser. Bot.) 46:5-83.

CARVALHO, J.C.M. 1945. Mirídeos Neotropicais, gêneros Diaphinidia Uhler, Hyaliodes Reuter, Hyaliodocoris Knight, Sinervus Stal e Spartacus Distant, com descrições de espécies novas. Bol. Mus. Nac. Nova Série, Zoologia (36):361-379.

CARVALHO, J.C.M. 1951. Mirideos Neotropicais, XXXIX: sobre duas espécies novas do Brasil (Hemiptera). Soc. Science. Fenn. 12 (7):1-6.

CHAPMAN, R.F. 1998. The insects: Structure and Function. 4 ed. Cambridge University, Cambridge, 770p.

COSTELLO, S.L., PRATT, P.D., RAYACHHETRY, M.B. \& CENTER, T.D. 2002. Morphology and life history characteristics of Podisus mucronatus (Heteroptera: Pentatomidae). Fla. Entomol. 85(2):344-356.

FERRAZ, A.S. 1980. Elementos de Trigonometria Esférica. ed. UFV, Imprensa Universitária, Viçosa, 23p. FERREIRA, P.S.F., PIRES, E.M., GUEDES, R.N.C., MENDES, M. \& COELHO, L.A. 2006. Seasonal abundance and sexual variation in morphometric traits of Oxelytrum discicolle (Brulle 1840) (Coleoptera: Silphidae) in a Brazilian Atlantic Forest. Biota Neotrop. 6(2):1-7.

FERREIRA, P.S.F \& VILELA, E.F. 1980. Estudo da variação geográfica de Polymerus testaceips (Stäl) (Hemiptera: Miridae) no Brasil, por meio de caracteres morfométricos. Ceres 27(151):313-319. 
FREY, J.E., LATSCHA, T. \& MCKEY, D.B. 1990. Genetic differentiation and speciation in leaf-mining flies of the genus Phytomyza. Entomol. esp. appl. 57:191-200.

GARNIER, S., GIDASZEWSKI, N., CHARLOT, M., RASPLUS, J.Y. \& ALIBERT, P. 2006. Hybridization, developmental stability, and functionality of morphological traits in the ground beetle Carabus solieri (Coleoptera, Carabidae). Biol J Linn Soc. 89(1):151-158.

GRAZIA, J. \& FREY-SILVA, A. 2001. Descrição dos imaturos de Loxa deducta Walker e Pallantia macunaíma Grazia (Heteroptera: Pentatomidae) em Ligustro, Ligustrum lucidum Ait. Neot. Entomol. 30(1):73-80.

LEHMANN, P., ORDOÑEZ, R., OJEDA-BARANDA, R., LIRA, J.M., HIDALGO-SOSA, L., MONROV, C. \& RAMSEY, J.M. 2005. Morphometric analysis of Triatoma dimidiata populations (Reduviidae:Triatominae) from Mexico and Northern Guatemala. Mem. Inst. Oswaldo Cruz 100(5):477-482.

LEMOS, W.P., RAMALHO, F.S., SERRÃO, J.E. \& ZANUNCIO, J.C. 2005 Morphology of female reproductive tract of the predator Podisus nigrispinus (Dallas) (Heteroptera: Pentatomidae) fed on different diets. Braz. Arch. Biol. Techn. 48(1):129-138,

MÖLLER, A.P. \& SWADDLE, J.P. 1997. Asymmetry, developmental stability and evolution. Oxford Series in ecology and evolution. Oxford University Press, Oxford. 291p.

MONTEIRO, L.R. \& REIS, S.F. 1999. Princípios de morfometria geométrica. Ed. Holos, Ribeirão Preto, SP, 198p.

RENTHAL, R., VELASQUEZ, D., OLMOS, D., HAMPTON, J. \& WERGIN, W.P. 2003. Structure and distribuition of antennal sensila of the red imported fire ant. Micron. 34(8):405-413.

PREZOTO, F. \& GOBBI, N. 2005. Morfometria dos estágios imaturos de Polistes simillimus Zikán 1951 (Hymenoptera: Vespidae). Rev. bras. Zoociências 7(1):47-54.
SAEG 9.0. 2006. Sistema para Análises Estatísticas Geral. Universidade Federal de Viçosa, Viçosa.

SANTOS, C.M., JURBERG, J., GALVÃO, C., ROCHA, D.S. \& FERNANDEZ, J.I.R. 2003. Estudo morfométrico do gênero Panstrongylus Berg 1879 (Hemíptera: Reduviidae: Triatominae). Mem. Inst. Oswaldo Cruz 98(7):939-944

SAS INSTITUTE. 2001. SAS User's Guide: Statistics, version 8.2. $6^{\text {th }}$ ed. SAS Institute, Cary, NC.

SEFFRIN, R.C.A.S., COSTA, E.C., COUTO, M.R.M. \& LOPES, S.J. 2006. Medidas morfométricas de fêmeas e machos de Oncideres dejeani Thompson 1868 (Coleoptera: Cerambycidae). Cienc. Rural 36(4):1313-1316.

SILVA, C.A.D., PIRES, E.M., LACERDA, M.C., PREZOTO, F., ZANUNCIO, J.C. \& SERRAO, J.E. 2006. Immature stages and nest characteristics of Apoica pallens (Hymenoptera: Vespidae). Sociobiol. 47(3):1-10.

SMITH, M.F. \& PATTON, J.L. 1988. Subspecies of pocket gophers: causal bases for geographic differentiation in Thomomys bottae. Syst. Zool. 37(2):163-178.

SMITH, E.S.C. 1979. Descriptions of the immature and adult stages of the cocoa mirid Helopeltis clavifer (Heteroptera: Miridae). Pac. Insect. 20(4):354-361.

TELLES, M.P.C., SILVA, R.S.M., CHAVES, L.J., COELHO, A.S.G. \& DINIZ FILHO, J.A.F. 2001. Divergência entre subpopulações de cagaiteira (Eugenia dysenterica) em resposta a padrões edáficos e distribuição espacial. Pesq. agropec. bras. 36(11):1387-1394.

Data Received 27/03/07

Revised 20/03/08

Accepted 01/04/08 